\title{
Analisis Pengelolaan Zakat di Pondok Modern Daarul Ilmi Menurut Hukum Islam dan UU NO. 23 Tahun 2011 tentang Pengelolaan Zakat
}

\author{
Rifa Ardi Gumelar*, Siska Lis Sulistiani \\ Prodi Hukum Keluarga Islam, Fakultas Syariah Universitas Islam Bandung \\ Bandung, Indonesia. \\ *Adialtar123@gmail.com, siscaassidq@yahoo.co.id
}

\begin{abstract}
Islam regulates zakat and its management as well as the law, the law governing zakat management is contained in Law Number 23 of 2011 concerning zakat management, which in Article 38 states that zakat management may not be carried out by any person without the approval of the authorities. Daarul Ilmi Islamic Boarding School has been carrying out zakat management activities since 2010 until now, but Daarul Ilmi Islamic Boarding School does not yet have legality from the authorities to manage zakat. This study aims to find out how to manage zakat according to Islamic law and Law Number 23 of 2011 concerning zakat management, and to find out how to manage zakat in Darul Ilmi Islamic Boarding School according to Islamic law and Law No. 23 of 2011 on zakat management. The method used in this study is juridical normative. In Islamic law, zakat management can be carried out by anyone without certain legalities, only to be appointed by a leader, but in Law Number 23 of 2011 Article 38 there must be legality or permission from the authorities, therefore Darul Islamic boarding school is appropriate or appropriate. In line with Islamic law regarding the management of zakat, but not according to Law Number 23 of 2011.
\end{abstract}

Keywords: Zakat, Zakat Management, Zakat Law.

Abstrak. Agama Islam mengatur mengenai zakat beserta pengelolaannya begitupun dengan UU. UU yang mengatur mengenai pengelolaan zakat terdapat pada UU No. 23 Tahun 2011 tentang pengelolaan zakat, yang mana pada Pasal 38 menyebutkan bahwa pengelolaan zakat tidak boleh dilakukan oleh sembarangan orang tanpa persetujuan dari pihak yang berwajib. Pondok Pesatren Daarul Ilmi telah melakukan kegiatan pengelolaan zakat semenjak Tahun 2010 hingga saat ini, akan tetapi Pondok Pesantren Daarul Ilmi belum mempunyai legalitas dari pihak yang berwajib untuk mengelola zakat. Penelitian ini bertujuan untuk mengetahui bagaimana pengelolaan zakat menurut hukum Islam dan UU No. 23 Tahun 2011 tentang pengelolaan zakat, serta mengetahui bagaimana pengelolaan zakat di Pondok Pesatren Darul Ilmi menurut hukum Islam dan UU No. 23 Tahun 2011 tentang pengelolaan zakat. Metode yang digunakan dalam penelitian ini adalah yuridis normatif. Di dalam hukum Islam pengelolaan zakat dapat dilakukan oleh siapa saja tanpa ada legaliats tertentu hanya ditunjuk oleh seoarang pemimpin, akan tetapi didalam UU No. 23 Tahun 2011 Pasal 38 harus adanya legalitas atau izin dari pihak yang berwajib, maka dari itu Pondok Pesantren Darul sudah sesuia atau sejalan dengan hukum Islam mengenai pengelolaan zakat, akan tetapi belum sesuai menurut UU No. 23 Tahun 2011.

Kata Kunci: Zakat, Pengelolaan, Undang-Undang, Hukum, Islam. 


\section{A. Pendahuluan}

Islam datang dengan aturan (syari'at) yang sempurna yang diturunkan demi kemaslahatan umat manusia secara menyeluruh. Oleh sebab itu, penerapan syari'at Islam baik dalam tataran individu maupun dalam skala masyarakat secara umum merupakan upaya Islam menjaga eksistensi dan keutuhan masyarakat. Artinya, penerapan syari'at Islam mengandung beberapa hikmah yang sangat besar dalam kehidupan, baik secara individu maupun kelompok. Secara etimologi, penerapan syariat adalah ilmu yang disertai amal (perbuatan) atau perkataan yang logis dan bermanfaat. Secara epistemologi, hikmah bermakna keutamaan dan kemuliaan yang mampu membuat pemiliknya menempatkan sesuatu secara proporsional dan berimbang. Selain dari pada itu islam juga memiliki dasar prinsip perekonomian umat yang tercatat dalam Firman Allah SWT:

"Supaya harta itu jangan beredar di antara orang-orang kaya saja di antara kamu..."(Qs. Al-Hasyr:7)

Manusia memiliki kebutuhan yang tak terbatas sementara sumber daya untuk memenuhi kebutuhan terbatas ketersediaannya. Akibatnya timbul kelangkaan, yang menurut paham ekonomi konvensional kelangkaan itu merupakan masalah ekonomi yang harus terpecahkan.

Salah satu ibadah yang mengandung hikmah besar dalam pembentukan ekonomi umat serta pribadi umat manusia adalah zakat.

UU zakat No. 23 Tahun 2011 tentang Pengelolaan Zakat, menyebutkan bahwa Zakat adalah harta yang wajib dikeluarkan oleh seorang muslim atau badan usaha untuk diberikan kepada yang berhak menerimanya sesuai dengan syariat Islam, diantaranya:

1. Fakir,

2. Miskin,

3. Amil,

4. Mu'allaf,

5. Riqab / Memerdekakan Budak,

6. Gharim (Orang yang Memiliki Hutang),

7. Fi Sabilillah.

Menurut Al-Qaradawi mengartikan fisabilillah dengan jihad, sebagaimana yang diartikan para ulama tafsir umumnya. Akan tetapi jihad yang dimaksudnya adalah jihad yang dilihat dari tujuan arti jihad yang sebenarnya. Dari elaborasi makna jihad inilah kemudian Al-Qaradawi menggunakan dalil hadist untuk menjelaskan makna jihad bukan hanya sekedar berjuang mengangkat senjata, berperang secara fisik melawan musuh Allah di medan perang namun jihad beragam cara dan objeknya. Selain itu juga al-Qaradawi telah menerapakan metode ijtihad ma'nawiyah, melalui qiyas dan istislah.

8. Ibnu Sabil.

Adapun peranan badan zakat nasioanal telah disebutkan dalam UU No. 23 Tahun 2011 tentang pengelolaan zakat pada Pasal 8 "Lembaga Amil Zakat yang selanjutnya disingkat LAZ adalah lembaga yang dibentuk masyarakat yang memiliki tugas membantu pengumpulan, pendistribusian, dan pendayagunaan zakat."

Dilihat dari fungsi serta alasan dibentuknya Badan Amil Zakat (BAZNAS) dan Lembaga Amil Zakat (LAZ), maka tidak boleh mendirikan Badan Amil Zakat tanpa seizin dari pihak yang berwenang (pemerintah) hal ini telah disebutkan dalam UU No. 23 Tahun 2011 tentang Pengelolaan Zakat pada Pasal 38, selain daripada itu orang yang bertindak selaku amil tanpa ada legalitas atau izin dari pihak yang berwenang maka dikenakan sanksi, hal itu tertera dalam Pasal 41.

Pondok Pesantren Daarul Ilmi salah satu pondok/yayasan yang berlokasi di Kabupaten Bandung Barat, setiap tahunnya rutin mengadakan penghimpunan atau pembayaran zakat fitrah semenjak Tahun 2010 hingga saat ini, akan tetapi pondok ini tidak memiliki legalitas sebagai Lembaga Amil Zakat dari pihak yang berwenang, hanya memiliki legalitas sebagai Pondok Pesantren dan yayasan. 
Hal ini sangat menarik, jika melihat syarat dalam Pasal 38 UU No. 23 Tahun 2011 tentang Pengelolaan Zakat. Oleh karena itu perlu kiranya dilakukan penelitian yang lebih jelas terhadap masalah tersebut. Dengan demikian apa yang melatar belakangi dan menjadi dasar Pondok Pesantren tersebut tetap menghimpun zakat fitrah setiap tahunnya, hal ini dapat dianalisis secara yuridis.

\section{B. Metodologi}

Menurut hukum Islam pengertian amil zakat secara bahasa, istilah amil berasal dari kata 'amila atau mengerjakan bermakna yang), كيْعَم ل-عِمَ Jalu'ya melakukan sesuatu. Kata amil عامل adalah ism fail yang bermakna pelaku dari suatu pekerjaan. Maka kata amil bermakna orang yang mengerjakan sesuatu. berikut:

Adapun pengertian amil zakat secara istilah menurut para ulama adalah sebagai

1. Menurut imam Syafi'i amil zakat adalah orang yang diangkat oleh wali/ penguasa untuk mengumpulkan zakat.

2. Menurut imam Hanafi amil zakat adalah orang yang dipekerjakan oleh Imam/ pemimpin untuk mengumpulkan zakat dan mereka digaji sesuai dengan kebutuhannya dan kebutuhan para karyawannya.

3. Menurut yusuf qardhawi amil zakat amilun adalah semua orang yang bekerja dalam perlengkapan administrasi urusan zakat, baik dalam urusan pengumpulan, pencatatan, penyimpanan, perhitungan maupun yang mencatat keluar masuk zakat dan membagi pada para mustahik-nya.

Setelah melihat definisi amil zakat diatas maka dapat disimpulkan bahwa amil zakat adalah orang-orang yang terlibat atau ikut aktif dalam kegiatan pelaksanaan zakat yang dimulai dari sejak pengumpulan zakat dari muzakki sampai pendistribusiannya kepada mustahik.

Adapun pengertian amil zakat menurut UU No. 23 Tahun 2011 sebagai berikut, terdapat dua lembaga resmi yang menjadi pengelola zakat di Indonesia yaitu BAZNAS dan LAZ. Pengertian Badan Amil Zakat Nasional atau BAZNAS terdapat pada UU No. 23 Tahun 2011 tentang Pengelolaan Zakat Pasal 1 ayat 7 "Badan Amil Zakat Nasional yang selanjutnya disebut BAZNAS adalah lembaga yang melakukan pengelolaan zakat secara nasional," sedangkan pengertian LAZ atau Lembaga Amil Zakat terdapat pada Pasal 1 ayat 8, "Lembaga Amil Zakat yang selanjutnya disingkat LAZ adalah lembaga yang dibentuk masyarakat yang memiliki tugas membantu pengumpulan, pendistribusian, dan pendayagunaan zakat"

Dasar hukum amil zakat dalam Islam terdapat pada Al-Qur'an

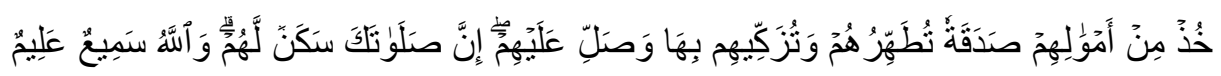

Artinya: "Ambillah zakat dari sebagian harta mereka, dengan zakat itu kamu membersihkan dan mensucikan mereka dan mendoalah untuk mereka. Sesungguhnya doa kamu itu (menjadi) ketenteraman jiwa bagi mereka. Dan Allah Maha mendengar lagi Maha mengetahui." (At Taubah 103)

Menurut Imam Ahmad Musthafa al-Maraghi meskipun ayat ini (At-Taubah ayat 103) memiliki sebab yang khusus, namun maknanya berlaku umum, artinya perintah ini tidak hanya kepada Nabi Muhammad Saw tetapi juga untuk para penganti-penganti Rasulullah seperti Khulafaurrasysdidin dan Ulil Amri atau pemimpin-pemimpin umat Islam sesudahnya.

Di samping itu dalam banyak hadis juga diterangkan, bahwa di saat Rasulullah menugaskan sahabat untuk menjadi gubernur di sebuah daerah, beliau selalu memberikan tugas kepada mereka yang diantaranya adalah perintah untuk memungut zakat dari orangorang kaya dan membagikannya kepada orang-orang miskin. Seperti pada saat Rasulullah mengutus Mu'az ibn Jabal menjadi gubernur di Yaman. Yang artinya:

Bahwa Rasulullah Saw mengutus Muaz ke yaman, kemudian Rasulullah berkata: "Serulah mereka untuk bersaksi Tiada Tuhan Kecuali Allah dan bahwa saya adalah utusan 
Allah, maka apabila mereka telah mematuhi hal itu, maka beritahukan kepada mereka bahwa Allah mewajibakan mereka shalat lima kali sehari semalam, dan apabila mereka telah mematuhinya, maka beritahukan kepada mereka bahwa mewajibklan zakat dari harta mereka, yang diambil dari orang kaya mereka dan bagikan kepada orang miskin di antara mereka. (HR Bukhari)

Pengelolaan zakat dapat berjalan dengan baik dengan dibentuk Badan Amil Zakat Nasional (BAZNAS) yang berkedudukan di Ibu Kota Negara, BAZNAS provinsi, dan BAZNAS kabupaten/kota. BAZNAS merupakan lembaga pemerintah nonstruktural yang bersifat mandiri dan bertanggung jawab kepada Presiden melalui Menteri. BAZNAS merupakan lembaga yang berwenang melakukan tugas pengelolaan zakat secara nasional.

Pelaksanaan pengumpulan, pendistribusian, dan pendayagunaan zakat yang dilakukan oleh BAZNAS, masyarakat juga dapat membantu dengan membentuk Lembaga Amil Zakat (LAZ). Pembentukan LAZ wajib mendapat izin Menteri atau pejabat yang ditunjuk oleh Menteri. LAZ wajib melaporkan secara berkala kepada BAZNAS atas pelaksanaan pengumpulan, pendistribusian, dan pendayagunaan zakat yang telah diaudit syariat dan keuangan, seperti yang telah diatur dalam UU No. 23 Tahun 2011 tentang Pengelolaan Zakat berikut:

\section{Pasal 5}

1. Untuk melaksanakan pengelolaan zakat, Pemerintah membentuk BAZNAS.

2. BAZNAS sebagaimana dimaksud pada ayat (1) berkedudukan di Ibu Kota Negara.

3. BAZNAS sebagaimana dimaksud pada ayat (1) merupakan lembaga pemerintah nonstruktural yang bersifat mandiri dan bertanggung jawab kepada Presiden melalui Menteri.

Pasal 6

BAZNAS merupakan lembaga yang berwenang melakukan tugas pengelolaan zakat secara nasional.

Selain BAZNAS ada juga LAZ, Lembaga Amil Zakat yang membantu BAZNAS dalam penghimpunan zakat seperti yang tercatat dalam UU No. 23 Tahun 2011 Pasal 1 ayat 8 "Lembaga Amil Zakat yang selanjutnya disebut LAZ adalah Lembaga yang dibentuk masyarakat yang memiliki tugas membantu pengumpulan, pendistribusian dan pendayagunaan zakat."

Seperti yang telah dijelaskan diatas dalam dasar hukum badan amil zakat, bahwa amil zakat mempunyai peranan penting terhadap pengelolaan zakat, maka dari itu tidak sembarang orang dapat menjadi amil zakat.

Di dalam kitab al-Ahkam as-Sulthaniyyah versi terjemahan, Imam al-Mawardi mengemukakanan bahwa syarat-syarat yang harus dimiliki petugas zakat ialah merdeka (bukan budak), muslim, adil, mengetahui hukum-hukum zakat jika ia pejabat menteri tafwidzi (plenipotentiary). Jika ia pejabat menteri tanfidz (pelaksana) yang diangkat imam untuk menarik zakat tertentu, maka dibenarkan kalau ia tidak mempunyai pengetahuan tentang hukum-hukum zakat. Dengan demikian, dapat disimpulkan bahwa dalam Islam, lembaga 'amil zakat itu adalah sifat perorangan yang mengurus zakat. Pada awal Islam amil zakat itu petugas zakat yang bersifat personal di bawah perintah Rasulullah, dan Khulafaurrasyiddin. Kemudian berkembang sehingga petugas zakat di bawah lembaga Baitul Mal. Sedangkan syarat-syarat amil zakat yaitu; muslim, adil, shiddiq, dan mengetahui hukum-hukum seputar zakat.

UU No. 23 Tahun 2011 telah mengatur syarat LAZ sebagai berikut:

\section{Pasal 18}

1. Pembentukan LAZ wajib mendapat izin Menteri atau pejabat yang ditunjuk oleh Menteri.

2. Izin sebagaimana dimaksud pada ayat (1) hanya diberikan apabila memenuhi persyaratan paling sedikit:

1. Terdaftar sebagai organisasi kemasyarakatan Islam yang mengelola bidang pendidikan, dakwah, dan sosial;

2. Berbentuk lembaga berbadan hukum; 
3. Mendapat rekomendasi dari BAZNAS;

4. Memiliki pengawas syariat;

5. Memiliki kemampuan teknis, administratif, dan keuangan untuk melaksanakan kegiatannya;

6. Bersifat nirlaba;

7. Memiliki program untuk mendayagunakan zakat bagi kesejahteraan umat; dan

8. Bersedia diaudit syariat dan keuangan secara berkala.

Pasal 3

1. Pembentukan LAZ sebagaimana dimaksud dalam Pasal 2 ayat (1) harus mendapat izin Menteri atau pejabat yang ditunjuk oleh Menteri.

2. Untuk mendapatkan izin sebagaimana yang dimaksud pada ayat (1) harus memenuhi persyaratan:

1. Terdaftar sebagai organisasi kemasyarakatan Islam yang mengelola bidang pendidikan, dakwah, dan sosial, atau lembaga berbadan hukum;

2. Mendapat rekomendasi dari BAZNAS;

3. Memiliki pengawas syariat;

4. Memiliki kemampuan teknis, administratif, dan keuangan untuk melaksanakan kegiatannya;

5. Bersifat nirlaba;

6. Memiliki program untuk mendaya gunakan zakat bagi kesejahteraan umat; dan

7. Bersedia diaudit syariah dan keuangan secara berkala.

Metode yang digunakan dalam penelitian ini adalah yuridis normatif

\section{Hasil dan Pembahasan}

Pengelolaan zakat dalam hukum Islam dapat dilakukan dilakukan oleh siapa saja atas perintah pemimpin, sedangkan pengelolaan zakat didalam UU No. 23 Tahun 2011 pada Pasal 38 tidak boleh sembarangan mengadakan kegiatan pengelolaan zakat oleh Lembaga ataupun orang yang tidak memiliki izin dari pihak yang berwenang.

Melihat dari hukum mengenai pengelolaan zakat yang terdapat dalam hukum Islam serta UU yang berlaku terhadap pengelolaan zakat maka kedua hukum ini jika dilihat secara sekilas maka kedua hukum ini bertentangan satu sama lain, akan tetepi hasil dari analisis penulis kedua hukum ini tidak bertentangan karna adanya teori maslahah, dan juga kaidah yang mendukungnya yaitu:

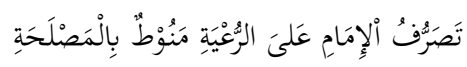

"tindakan atau kebijakan seorang pemimpin terhadap orang-orang yang dipimpinnya harus dikaitkan dengan kemaslahatan"

Pengelolaan zakat yang dilakukan oleh Pondok Pesantren Darul Ilmi itu sendiri adalah zakat fitrah, Pondok Pesatren Daarul Ilmi memulai pengelolaan zakat fitrah dimulai sejak Tahun 2010 dengan alasan untuk membantu perekonmian warga sekitar Pondok Pesantren Daarul Ilmi yang terbelakang, hal ini sesuai dengan teori yang terdapat dalam kajian teori hukum Islam yaitu teori maslahah.

Setelah melihat data serta wawancara yang telah dilakukan oleh penulis mengenai pengelolaan zakat di Pondok Pesantren Daarul Ilmi, yang kemudian di analisis dengan pengelolaan zakat menurut hukum Islam yang telah tertera didalam Al-Qur'an serta hadisthadist, maka pengelolaan zakat yang dilaksanakan di Pondok Daarul Ilmi telah sesui atupun sejalur dengan hukum Islam yang mengatur tentang pengelolaan zakat.

Pondok Pesantren Modern Daarul Ilmi belum mendapatkan izin dari pembentukan LAZ sesuai UU dan peraturan pemerintah tersebut. Peraturan legalitas yang terdapat pada UU No. 23 Tahun 2011 tentang Pelaksanaan Pengelolaan, yang mana diharuskannya mempunyai persetujuan untuk mengelola zakat dari pihak yang berwenang, maka dari itu pengelolaan zakat yang dilakukan oleh Pondok Pesatren Daarul Ilmi belum sejalan dengan UU No. 23 
Tahun 2011 tentang pengeloaan zakat, mengenai legalitasnya yang terdapat pada Pasal 38 .

\section{Kesimpulan}

1. Hukum Islam dan UU mempunyai aturan serta hukum yang berbeda mengenai pengelolaan zakat, yang mana di dalam hukum Islam untuk mengelola zakat atau menjadi amil zakat hanya perlu ditunjuk langsung oleh amir atau pemimpin, lain hal dengan Undang-Undang yang mana mengatur beserta syarat-syaratnya untuk mendapatkan izin untuk melaksanakan pengelolaan zakat yang terulis dalam UU No. 23 Tahun 2011 tentang pengelolan zakat. Melihat kedua hukum ini mengenai pengelolaan zakat terlintas bertentangan akan tetapi tidak karna didalam hukum ada yang namanya teori maslahah yang mana teori ini menyelaraskan antara pengelolaan zakat menurut hukum Islam serta pengelolaan zakat menurut UU No. 23 Tahun 2011 tentang Pengelolaan Zakat.

2. Pondok Pesatren Daarul Ilmi adalah salah satu pondok pesantren yang melaku kegiatan pengelolaan zakat terutama zakat fitrah yang hampir setiap tahunnya melakukan pengelolaan zakat fitrah tersebut, kegiatan pengelolaan zakat yang dilakukan oleh Pondok Pesantren Daarul Ilmi telah berjalan sejak Tahun 2010 sampai dengan saat ini, secara garis besar menurut hukum Islam kegiatan pengelolaan zakat yang dilakukan Pondok Pesatren Daarul Ilmi itu telah sesui dengan aturan-aturan tentang pengelolaan zakat yang telah tercantum didalam Al-Qur'an dan hadist, terutama tentang masalah legalitasnya terhadap amil zakat, karena yang digaris bawahi oleh peneliti terhadap penelitian ini adalah legalitasnya.

3. Indonesia telah mengatur pengelolaan zakat didalam UU zakat No. 23 Tahun 2011 tentang Pengelolaan Zakat, didalam UU tersebut mengatur tentang legalitas Lembaga pengelolaan zakat yang terdapat pada Pasal 38 serta syarat-syarat untuk menjadi Lembaga yang mengelola zakat. Pondok Pesantren Daarul Ilmi telah melakukan kegiatan pengelolaan zakat akan tetapi belum mempunyai legalitas resmi dari pemerintah atau pejabat yang berwenang untuk mengelola zakat, maka dari itu legalitas pengelolaan zakat di pondok pesatren Daarul Ilmi belum sejalan atau sesuai dengan UU No. 23 Tahun 2011 tentang Pengelolaan Zakat.

\section{Daftar Pustaka}

[1] Tika Widiastuti, Hand Book Zakat, Surabaya : Airlangga University Press, 2019.

[2] Munawir Sadzali, Zakat dan Pajak, Jakarta: Bina Rena Pariwara, 1991.

[3] Wawancara dengan Ismail Paji Alwathan, Ketua Pengasuhan Pondok Pesantren Daarul Ilmi, Tanggal 11 Januari 2021

[4] Hanif luthfi, siapakah amil zakat, Jakarta Selatan : Rumah Fiqih Publishing, 2018.

[5] Widi nopiardo, urgensi berzakat melalui amil dalam pandangan ilmu ekonomi islam, Jurnal Ilmia Syari'ah Volume 15 no 1, 2016.

[6] Undang-Undang No. 23 Tahun 2011 Tentang Pengelolaan Zakat.

[7] Salam Qur'an: Al-Qur'anul Karim Dan Terjemah Edisi Keluarga

[8] Arif Zunzul Maizal, Berzakat Melalui Amil Dalam Perspektif Al-Qur'an Dan Sunnah, Jurnal Al-Fuad, Vol.I, No. 1, Juli-Desember 2017.

[9] Ahmad Gunawan, Posisi Dan Metode Ijtihad Yusuf Al-Qaradawi Tentang Fisabilillah Sebagai Asnaf Mustahiq Zakat Dalam Perbandingan Empat Mazhab, TAHKIM, Jurnal Peradaban dan Hukum Islam. Vol.2 No.1 (Maret, 2019)

[10] Admin, "penelola zaka", dalam https://www.jogloabang.com/pustaka/uu-23-2011pengelolaan-zakat diakses pada 04 maret 2021, pukul 09:26

[11] Bambang Reza Astoni, Kewenangan Pengangkatan Amil Zakat (Studi Perbandingan Fiqih Dan Hukum Positif) Fakultas Syari'ah Dan Hukum Universitas Islam Negeri Ar-Raniry Darussalam-Banda Aceh

[12] Konseptualisasi Teori Maslahah, Asmawi 1salam; Jurnal Filsafat Dan Budaya Hukum. 